\title{
Research on Method of the Heavy Traffic Airport Cement Concrete Pavement Thickness Design
}

\author{
Wei $\mathrm{Wu}^{1, \mathrm{a}}$, Jianwu Wang ${ }^{2, \text { a }}$, Chao Zhang ${ }^{1, \text { a }}$, Qingkun $\mathrm{Yu}^{2 \text {, a }}$ \\ ${ }^{1}$ Department of Airfield Engineering and Support, Air Force Logistics College, Xuzhou 221000, \\ China \\ ${ }^{2}$ Cadet Brigade 1, Air Force Logistics College, Xuzhou 221000, China \\ ${ }^{a}$ cemail917588484@qq.com
}

Keywords: Pavement thickness design; heavy traffic; fatigue equation.

\begin{abstract}
This paper describes the traditional design methods for airport pavement thickness and noted deficiencies, and pass through the cumulative damage theory - coverage of theory, the choice of NCHRP 1-26 fatigue equation is proposed for heavy traffic airport cement concrete pavement thickness design methods.
\end{abstract}

\section{Introduction}

In recent years, airport security and the type of aircraft sorties increased aircraft load has been improved to some extent. In addition, the security architecture model type landing increasingly complex. Airport pavement thickness and design methods have higher requirements. For airport cement concrete pavement thickness calculation, domestic and foreign military and civilian airport pavement design specifications are used to specify a certain type of aircraft as a design model, other aircraft movements will be converted into design models undercarriage times, and then according to the design models The total thickness of the pavement landing times conduct calculations.

\section{Traditional design methods and their limitations}

The traditional method for determining the thickness of the pavement below [1]: Selected for pavement thickness requirements largest aircraft design aircraft; Respectively, according to the above formula will be converted to run on a number of other aircraft design aircraft equivalent number of years running; the various models of the design (conversion) is added to the annual average number of runs, we can get the airport running annual average number of aircraft.

$$
N_{d i}=\left(\delta N_{i}\right) \sqrt{\left(\frac{P_{i}}{P_{S}}\right)}
$$

Where: design aircraft converted into equivalent annual average number of runs; conversion of aircraft for the average number of runs intended to be determined by the investigation and forecasting; design wheel load (KN) main landing gear on the aircraft; the aircraft is intended to convert the main wheel load on the landing gear (KN); for landing architecture type conversion factor. Flexural tensile strength of concrete is calculated based on fatigue equation; Sugared resilient modulus and base (cushion) layer of material and thickness to determine the equivalent resilient modulus based on the top surface of the grassroots; Calculate resilient modulus grassroots top surface; Preliminary estimates suggest that the thickness; It is calculated under load stress modulus and joint load transfer coefficient, check the appropriate chart, was designed to load; If not exceeded by the calculated \pm $2.5 \%$, it is assumed that the plate thickness is reasonable; otherwise again assumed, repeating steps (7) to (9), until it meets the requirements. In this design method, the thickness of the pavement when a different type of aircraft regarded as a design will be different. Under heavy traffic conditions, the type of aircraft the growing proliferation of airport operations, landing gear load parameters are also diverse, plus a variety of combinations of pavement structure system. To convert the aircraft to a certain degree of difficulty, leading to decline in terms of accuracy.

Run under heavy traffic conditions aircraft generally have heavier wheel loads, landing architecture type complex, wheels and more features [2]. The traditional airport cement concrete 
pavement thickness design method only supports up to four load analysis, and unable to adapt to large aircraft under heavy traffic conditions. Some aircraft maximum take-off weight of hundreds of tons, conventional aircraft weight disparity, making the mainframe inside the heavy traffic composition complex, traditional design methods cannot effectively consider such heavy traffic.

\section{Design Principles and Standards}

In recent years, research on the problem of heavy traffic on the gradual deepening of international, a new method based on the principle of cumulative damage. In this method, Miner's law as the theoretical basis of different loads on aircraft pavement fatigue damage generated by linear superposition, the degree of fatigue damage accumulated determining whether the pavement fatigue damage state. This design approach not only avoids the conversion between different aircraft and aircraft design, and can be considered material parameters over time decay law, as compared with the traditional method of design of aircraft, more scientific and reasonable.

In the actual pavement thickness design to cumulative damage factor $\mathrm{CDF}^{[3]}$ (Cumulative damage factor) to measure the effect of fatigue produced under a variety of aircraft. Cumulative damage factor CDF is the characterizations of pavement role in a variety of models have been used in the fatigue life can be obtained by linear superposition of various models, see (2).

$$
\begin{aligned}
& C D F=\sum_{i=1}^{k} C D F_{i}=\sum_{i=1}^{k} \frac{n_{i}}{N_{i}} \\
& n_{i}=\frac{N_{t} \times t}{P / C}
\end{aligned}
$$

Where: $n_{i}$ into aircraft to allow coverage number is determined by (3); $N_{t}$ for the first year I kind of aircraft sorties off; $t$ the total number of aircraft in use: $P / C$ for the design life; $N_{i}$ for passage coverage; for it aircraft sorties year off, the stress level by fatigue equation and the aircraft produced in the road surface. Airport pavement design method under heavy traffic conditions can be employed in fatigue cracking concrete slab reaches a certain level as pavement design standards to CDF size to determine its reasonableness, CDF and design standard correspondence between damage control as follows:

When $\mathrm{CDF}=1$, the pavement to reach damaged when it reaches the designed standard reference period; When $\mathrm{CDF}<1$, pavement design reference period is reached, the standard has not yet reached the damage, more than life; When $\mathrm{CDF}>1$, while not yet reached the pavement design standard reference period reached damage, inadequate life. Different types of damage correspond to a CDF value. As to fatigue cracking of the surface layer is damaged as a standard available CDF. Sub grade vertical compressive strain to destroy another available as standard CDF. Pavement structure design should be able to meet the different requirements of damage.

\section{Calculation Method}

Aircraft effect of pavement structures pass through the landing gear wheels. When the plane passed, the number of times a certain point the role of road surface by a tire called folds. In some areas of low probability of tire role, covering the number may be less than the number of traffic aircraft tire role in a high probability area, covering the number could be close to the number of aircraft traffic. Cement concrete pavement design uses a lot of board edge to fatigue cracking of the standard design patterns, in the plane load repetition effect, there is a certain amount of cement concrete pavement fatigue life allowing fold. Allows you to override the number and fatigue characteristics of cement concrete, closely related to aircraft loads and environmental factors such as stress levels, and its value can be determined by the level of stress and fatigue equation aircraft produced in the road surface. For many years, at home and abroad on the fatigue characteristics of cement concrete pavement were a lot of ongoing research, the fatigue equation applicable to many different conditions using different experimental techniques. Sorting out the previous linear fatigue equation: $\frac{\sigma}{f_{r}}=a-b \log N_{f}$ Military airport using simply supported concrete fatigue testing laboratory conducted regression analysis of concrete fatigue equation: $\frac{\sigma}{f_{r}}=0.944-0.077 \log N_{f}$ Aviation has indoor flexural fatigue test 
results-based, taking $99.7 \%$ security guarantee rate resulting fatigue equation : $\frac{\sigma}{f_{r}}=0.885-$ $0.063 \log N_{f}$ US NCHRP 1-26 fatigue equation using the finite element method to calculate the stress, the full integration of indoor and outdoor test results and theoretical research road and airport pavement, closer to the actual state. By comparison (see Table I), recommended NCHRP 1-26 fatigue equation (see equation (4)) and establishing airport pavement design method under heavy traffic.

Sorting out the previous linear fatigue equation:, military airport using simply supported concrete fatigue testing laboratory conducted regression analysis of concrete fatigue equation; Civil Aviation has indoor flexural fatigue test results-based, taking $99.7 \%$ safe guaranteed rate resulting fatigue equation: US NCHRP 1-26 fatigue equation using the finite element method to calculate the stress, the full integration of indoor and outdoor test results and theoretical research road and airport pavement, closer to the actual state. Therefore, we recommend using the NCHRP 1-26 fatigue equation (see equation (4)) to establish airport pavement design method under heavy traffic adaptation.

$$
\begin{cases}\log C=-1.7136 \frac{\sigma_{e}}{f_{r}}+4.284 & \frac{\sigma_{e}}{f_{r}}>1.25 \\ \log C=2.8127\left(\frac{\sigma_{e}}{f_{r}}\right)^{-1.2214} & \frac{\sigma_{e}}{f_{r}}<1.25\end{cases}
$$

(4)

Where: $C$ is the number of plates covering $50 \%$ of cracking; $\sigma_{e}$ is Maximum stress for board edge.

Table I. Contrast foreign fatigue equation

\begin{tabular}{|c|c|c|c|c|c|c|}
\hline \multirow[b]{2}{*}{$\begin{array}{l}\text { Fatigue } \\
\text { equation }\end{array}$} & \multirow[b]{2}{*}{ Data Sources } & \multirow[b]{2}{*}{ Damage state } & \multicolumn{3}{|c|}{ The amount of stress response } & \multirow[b]{2}{*}{$\begin{array}{l}\text { Concrete } \\
\text { strength }\end{array}$} \\
\hline & & & Location & Type & $\begin{array}{l}\text { Calculation } \\
\text { Method }\end{array}$ & \\
\hline $\begin{array}{c}\text { COE- } \\
\text { West guard }\end{array}$ & Cofield data & $\begin{array}{l}50 \% \text { of the } \\
\text { board of } \\
\text { cracking }\end{array}$ & $\begin{array}{r}\text { Board } \\
\text { edge } \times 0.75\end{array}$ & Loads & Western guard & $\begin{array}{l}\text { Flexural } \\
\text { strength } \\
\text { (Different } \\
\text { ages) }\end{array}$ \\
\hline COE-LEA & Cofield data & $\begin{array}{l}50 \% \text { of the } \\
\text { board of } \\
\text { cracking }\end{array}$ & $\begin{array}{l}\text { Board } \\
\text { edge }\end{array}$ & Loads & Elasticity & $\begin{array}{l}\text { Flexural } \\
\text { strength } \\
\text { (Different } \\
\text { ages) }\end{array}$ \\
\hline FAA & Cofield data & $\begin{array}{l}50 \% \text { of the } \\
\text { board of } \\
\text { cracking }\end{array}$ & $\begin{array}{r}\text { Board } \\
\text { edge } \times 0.75\end{array}$ & Loads & Western guard & $\begin{array}{l}\text { Flexural } \\
\text { strength } \\
\text { (Different } \\
\text { ages) }\end{array}$ \\
\hline LEDFAA & Cofield data & $\begin{array}{l}50 \% \text { of the } \\
\text { board of } \\
\text { cracking }\end{array}$ & $\begin{array}{r}\text { Board } \\
\text { edge } \times 0.75\end{array}$ & Loads & $\begin{array}{l}\text { Elastic } \\
\text { layer state } \\
\text { system }\end{array}$ & $\begin{array}{l}\text { Flexural } \\
\text { strength } \\
\text { (Different } \\
\text { ages) }\end{array}$ \\
\hline $\begin{array}{l}\text { NCHRP } \\
1-26\end{array}$ & $\begin{array}{l}\text { COEField data } \\
\text { and AASHORoad } \\
\text { Test }\end{array}$ & $\begin{array}{l}50 \% \text { of the } \\
\text { board of } \\
\text { cracking }\end{array}$ & $\begin{array}{l}\text { Board } \\
\text { edge }\end{array}$ & $\begin{array}{l}\text { Loads and } \\
\text { Temperature }\end{array}$ & FEM & $\begin{array}{l}\text { Flexural } \\
\text { strength } \\
\text { (Different } \\
\text { ages) }\end{array}$ \\
\hline PCA & $\begin{array}{l}\text { Concrete } \\
\text { beams }\end{array}$ & $\begin{array}{c}\text { Liang } \\
\text { completely } \\
\text { broken }\end{array}$ & $\begin{array}{l}\text { Floor } \\
\text { beams }\end{array}$ & Loads & $\begin{array}{l}\text { Beam } \\
\text { bending } \\
\text { equation }\end{array}$ & $\begin{array}{l}\text { Flexural } \\
\text { strength } \\
\text { (Different } \\
\text { ages) }\end{array}$ \\
\hline
\end{tabular}

The number of aircraft on the airport pavement overlay thickness design is crucial, but often cannot get coverage through direct observation need to be estimated. Number of factors and the role of the models covered by the number of times the number of the main landing gear and wheelbase, width and wheel tracks of the lateral distribution of the relevant tire contact area. Pavement thickness design commonly used traffic - Comprehensive coverage to reflect the above-mentioned factors. 
By $N_{c}=\frac{N_{j} \eta N W_{t}}{100 T}$ and (3) can be derived cement concrete pavement design is used to calculate the passage - coverage formula is as follows:

$$
\frac{P}{C}=\frac{T}{\eta n_{\omega} W_{t}}
$$

\section{Design Flow}

Combination of the above, have to adapt to the airport pavement thickness design flow under heavy traffic conditions, as shown below:

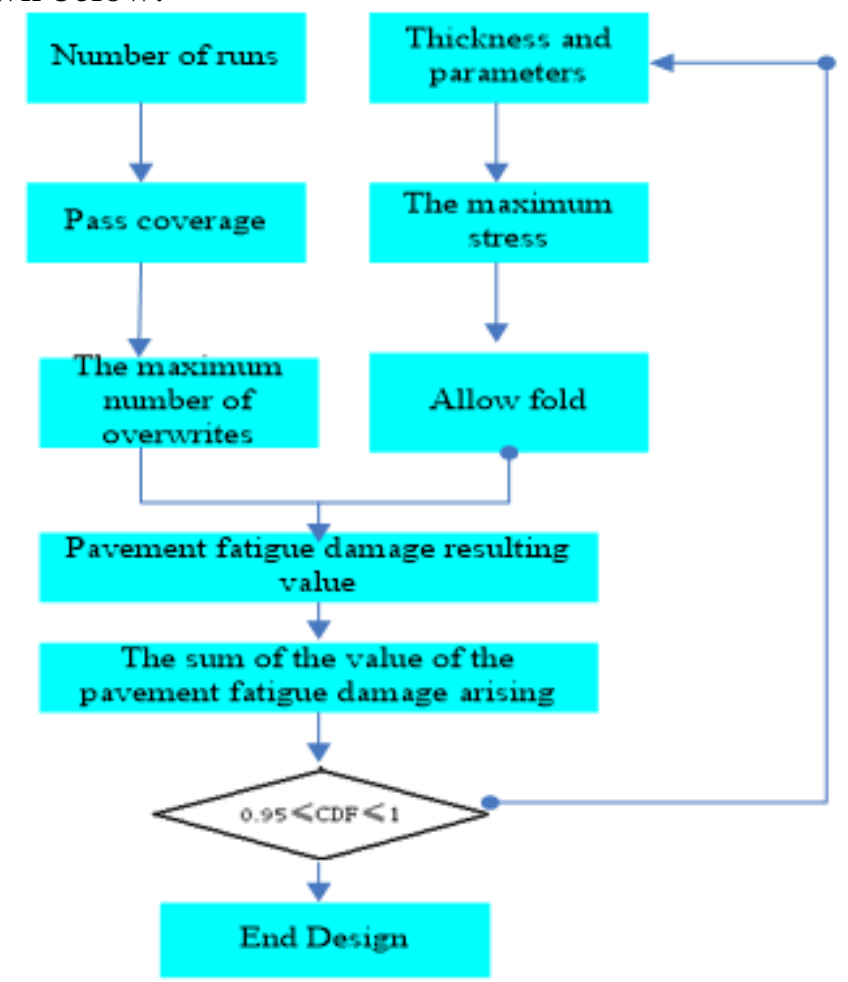

Figure 1. Airport pavement thickness design flow under heavy traffic

\section{Summary}

In this paper, heavy wheel loads and complex architecture shaped landing under heavy traffic conditions, through theoretical analysis, summarized, the principle of cement concrete pavement thickness design, standards, thickness calculation methods, processes, etc. has been systematically studied, the main conclusions as follows: Introduces the method and its lack of existing pavement design specification adopted; The equivalent damage and aircraft traffic in the road surface - such as coverage of new theories, methods and theory to establish a reasonable airport pavement design thickness under heavy traffic. Compared with existing methods, the new method is more simple calculation method is more scientific theory; Integrated proposed airport pavement thickness design flow under accommodate heavy traffic conditions.

\section{References}

[1] Luo Zhaojun, Wang Feng, Liang Jifeng airport design [M] Xuzhou: Blue Sky Press. 2014.

[2] Chiang Ying-jun, Daijing Liang heavy traffic of cement concrete pavement [M]. Beijing: China Science and Technology Press. 2010.

[3] Li Qiaosheng, ZHAO Duo, and Ling Jianming accommodate large special aircraft airport cement concrete pavement structural design method [J] Civil Engineering Journal: 2011, 44 (1). 